\title{
DA SOBERANIA JURÍDICA À NACIONALIDADE: DA LOCALIZAÇÃO ESTATAL À DESLOCALIZAÇÃO ESPORTIVA
}

\author{
Ramon Negócio \\ Centro Universitário 7 de Setembro (UNI7), Ceará \\ negocioramon@gmail.com
}

\begin{abstract}
RESUMO: Este trabalho objetiva analisar como conceitos de soberania, cidadania e nacionalidade - tradicionalmente do direito público - são ressignificados pelo direito desportivo. $\mathrm{O}$ artigo parte da premissa de que a globalização já transformou a nossa forma de ver o Estado. O Estado e a sua estatalidade passam a conviver também com atores privados. A percepção sobre território, povo e monopólio da sanção ganham novos atores de controle. Com isso, faz-se necessário diferenciar soberania jurídica da soberania política para explicar a validade das decisões de estruturas globais privadas, tal como a lex sportiva. Pautada na autonomia privada, a ordem desportiva consegue ser efetiva por causa de seu caráter associativo e de sua hierarquia. A partir de casos concretos e pesquisa bibliográfica, o Tribunal Arbitral do Esporte consegue aplicar, dentro de sua lógica interna, a ideia de soberania jurídica, cidadania e nacionalidade para garantir a igualdade desportiva. As conclusões apontam que alguns conceitos tradicionais do direito público não dão mais conta de explicar a atuação de atores privados globais, necessitando, assim, de uma reatualização.
\end{abstract}

PALAVRAS-CHAVE: Globalização. Lex sportiva. Soberania. Cidadania. Nacionalidade.

\section{From legal sovereignty to nationality: from state location to sports delocalization}

\begin{abstract}
This paper aims at analyzing how the concepts of sovereignty, citizenship and nationality - traditionally ascribed to public law - are re-signified in the realm of sports law. The paper starts off with the premise that globalization has already transformed our way of looking at the state. Now the state begins to coexist with private actors. The perception of territory, people and the monopoly of sanction gains, by that token, new controlling actors. Thus, it is absolutely necessary to differentiate between legal sovereignty and political sovereignty in order to explain the validity of decisions made by private global structures such as lex sportiva. Resting on private autonomy, the sports order manages to be effective because of its associative character and hierarchy. Based on concrete cases, the Court of Arbitration for Sport manages to apply within its internal logic the idea of legal sovereignty, citizenship and nationality in order to guarantee sports equality. The conclusions suggest that some traditional public law concepts no longer account for the performance of global private actors, thus urging to be updated.
\end{abstract}

KEYWORDS: Globalization. Lex sportiva. Sovereignty. Citizenship. Nationality.

\section{INTRODUÇÃO}

A imagem de ex-presidentes da FIFA, como Joseph Blatter e João Havelange, ou do Comitê Olímpico Internacional, como Juan Antonio Samaranch e Jacques Rogge, sendo recebidos como Chefes de Estado nunca foi incomum. Apesar de não representarem um único país, tais representações falavam em nome de mais de duzentos membros (mais do que a ONU, por exemplo). Entidades desportivas como essa são organizações privadas com alto grau de vinculação a 
seus membros em torno de suas regras. O tema, mais que se encaixar em uma percepção transconstitucional, exige uma nova reflexão sobre conceitos tradicionalmente do direito público ressignificados pelo direito privado. A partir das ideias de "soberania", "cidadania" e "nacionalidade", este artigo visa apresentar como a lógica associativa de atores privados dá nova aplicabilidade a conceitos constitucionalmente estabelecidos.

\section{GlOBAlizaÇÃo COMO CONDICIONANTE dA ESTATALIDADE}

Não foram poucas vezes que a literatura jurídica tratou da transformação da estatalidade (Staatlichkeit) frente a participação internacional, supranacional e de atores privados com papeis estatais. Esse papel do Estado em movimento fragmentário (ou diluído) se associava a uma sociedade mundial (Weltgesellschaft), tornando a localidade menos relevante como condição de possibilidade de ver e ouvir (LUHMANN, 2000, p. 220). Em uma sociedade mundial, os Estados se tornam dependentes entre si. A soberania (com sua função de proteção) perde força diante de uma responsabilidade com ordens regionais. Surge uma conexão heterárquica e em rede de comunicações tanto nos níveis de organizações quanto no das profissões - ainda mais aprofundada com a internet (LUHMANN, 2000, p. 221). Todavia, isso não é suficiente para negar a diferenciação segmentária do sistema político - delimitada pelo território -, que serve para introduzir condições de diferenças e semelhanças dos segmentos: "Isto é feito reduzindo a igualdade à 'estatalidade' e a estatalidade à competência de comunicação organizada” (LUHMANN, 2000, p. 227). Isso ainda se aprofunda com o poder de regulação e tomada de decisão de atores privados, que também vinculam Estados.

Nesse contexto de mudança da estatalidade, Teubner defende que há um remodelamento das instituições constitucionais nacionais. Porém, isso acaba por ser um campo de possibilidades que promove instituições constitucionais e democráticas em uma nova forma da sociedade mundial diante de "um sistema de negociação transnacional entre atores coletivos globais" e "uma restrição constitucional do poder social nos processos políticos globais" (2012, p. 13). Diferentemente de Luhmann, Teubner é mais radical na percepção da descentralização das funções do Estado, de modo que autoriza o aparecimento de atores globais da sociedade civil, que produzem seu próprio direito em torno de temas como economia global, meio ambiente, tecnologia etc.. Tal radicalidade coloca o Estado numa relação de horizontalidade, isto é, heterárquica com atores privados (FISCHER-LESCANO; TEUBNER, 2006, p. 16-19).

Para Teubner, a lógica normativa interna de atores privados transnacionais se desgruda da validade normativa estatal. Isso não nega a possibilidade de construção interna pautada em regras primárias e secundárias, mas, nesse caso, os códigos estatais não servem como base de validade dos códigos privados. Estes teriam sua validade em "uma combinação independente de normas primárias e secundárias no mundo da ordem privada" (2012, 81-82). O direito internacional ainda permanece relevante nesse modelo. Todavia, coloca outros atores não tradicionais como relevantes no discurso jurídico, o que apresentaria três novos desafios para a soberania estatal:

\footnotetext{
First, supra-national norms and structures (international human rights law, the WTO) impinge upon sovereignty in unprecedented ways. The claim here is not that states have been hermetically sealed up to this point; it is rather that interference in state sovereignty is now being justified in legal terms that carry increasing weight around the world. Second, subnational groups are demanding (and receiving) increasing degrees of autonomy [...]. The third dimension along which sovereignty is under challenge as "transnationalism" - the presence within state borders of communities of non-nationals with significant ties across borders (ALEINIKOFF, 2000, p. 202).
} 
O que se percebe é que a estatalidade está em "uma mudança funcional fundamental nos processos de desagregação dos subsistemas sociais" (FISCHER-LESCANO; TEUBNER, 2006, p. 159). Assim, crescem as atividades de organizações paraestatais, exigindo uma nova coordenação com outras fontes não mais tradicionalmente legais (MAYER, 2005, p. 175). O critério hierárquico das fontes do direito é relativizado em um contexto de fortes influxos externos, demandando um alargamento que inclue tanto as regras dentro e fora do Estado (VESTING, 2015, p. 91). O direito do Estado, cada vez mais cognitivo no sentido de uma cooperação, deixa de se tornar de autoridade central, pois cria ligações com diferentes Estados, poderes públicos, associações, economia e ciência (DI FABIO, 1998, p. 145). A unidade estrutural do Estado entre direito e política parece se diluir (DI FABIO, 1998, p. 145), colocando o Estado em uma rede de relações. Assim, não só a soberania passa por mudanças, mas também as relações de direito público e o Estado (VESTING, 2003, p. 42). Em um contexto transnacional, isso resulta em uma mútua influência, que aceita a produção de convenções, regras e padrões decentralizados e autônomos, de modo que haveria uma "concorrência legislativa" (Gesetzgebungswettbewerb) que exigiria uma rede flexível de fontes de direito, gerando, também, uma heterarquia de fontes (VESTING, 2015, p. 112). O direito do Estado na sociedade mundial exige uma confrontação com outras esferas globais e suas respectivas ordens normativas, tornando suas relações mais flexíveis ao invés de se seguir uma única lógica territorial (VESTING, 2003, p. 59).

A narrativa sobre a transnacionalização do direito sugere não necessariamente o bloqueio regulatório do Estado, senão um crescente processo de autorregulação ou corregulação tendo em vista traços legitimatórios ${ }^{1}$, mas, contextualmente, inclui e exclui determinados atores estatais e internacionais, para evitar a excessiva politização e burocratização de soluções eminentemente técnicas (BOTZEM, 2005).

A estatalidade está intimamente entrelaçada pelo seu território, povo e concentração do uso da força por parte do Estado: "o povo traduz-se em uma comunidade reunida legal e culturalmente" (KOKOTT, 2003, p. 12); "o território é o âmbito de delimitação do uso da força, sua sanção, entendendo a hierarquia do Estado" (KOKOTT, 2003, p. 14). Essas duas ideias demandam ressignificação, não só pelo contexto do direito comunitário e de integração, mas também pelo fenômeno associativo global. Assim, a concentração da força no Estado passa ser mitigada.

Se já se entende que a globalização e o aparecimento de outros atores condicionam a estatalidade e dá um lugar diferente para os Estados, resta entender, de modo concreto, como a estrutura privada da lex sportiva é vinculante. A segmentação do Estado se dilui num processo associativo, cuja regulação de atores privados por meio de códigos desportivos redimensiona o papel de atores estatais e internacionais.

\section{ESTRUTUTRA DA LEX SPORTIVA E VINCULAÇÃO ASSOCIATIVA}

O direito desportivo possui uma estrutura autorregulatória que viabiliza retorno concreto de decisões, reduzindo incertezas em função da falta de conhecimento específico do Estado (LEYENS, 2015, p. 614). Cumpre, assim, a função de uma ordem jurídica para estabilizar expectativas normativas e orientar condutas a partir do controle das regras em nome do grupo (LEYENS,

\footnotetext{
1 Em outro sentido de co-participação, afirma Perrit: "Criteria for private governance must include standards for determining real consent-and thus activating a contractual matrix for private regulation. When consent is not the legitimating engine of private governance, public legal institutions must specify criteria entitling private regulatory regimes to deference or immunity, and conversely apply standards for civil liability. For private regulatory regimes with direct effect-exercise of private power to exclude persons from desirable resources-private rights of action must allow challenges to impermissible private regulatory decisions. The content of these rights of action should reflect public concerns", (PERRITT JR., 2001, 216).
} 
2015, p. 615), ou, mais precisamente, nos termos de vinculação que transcendam as partes envolvidas em uma lide. Entre o lance que define o título da Libertadores de 2019 e uma decisão antidopagem da Corte Arbitral do Esporte (TAS ou CAS), existe uma estrutura hierárquica que estabelece os direitos e deveres e identifica quem produz e julga normas. Tal estrutura transcende o campo de jogo, dado que este pressupõe todas as regras pré-estabelecidas.

A vinculação de atores desportivos é dependente da estrutura olímpica ${ }^{2}$ desportiva, que inclui as Federações (ou Confederações) Nacionais de esporte. Estas legitimam um atleta a participar localmente de uma competição, atestando a validade de vitórias, campeonatos e recordes ${ }^{3}$. A ambição ou a potencialidade de se internacionalizar o esporte faz surgir a necessidade de reconhecimento de uma Federação Internacional, cuja função - além de organizar as competições internacionais - é validar a inclusão de atores desportivos nacionais.

Assim, por mais que a atividade física ou o esporte tenha uma grande aderência ou que um determinado atleta amador possua mais talento do que um federado, o processo vinculatório só existirá com a formalização e reconhecimento de uma estrutura esportiva (como ocorre no âmbito Olímpico).

Em grande medida, a maioria das organizações esportivas buscam nas Olimpíadas apresentar suas competições e seus melhores atletas em sua plenitude. É nessa competição que há maior visibilidade comercial.

Para uma Federação poder ter seu esporte sendo apresentado mundialmente nesse evento, dependerá de reconhecimento do Comitê Olímpico Internacional (COI), que possui sua dimensão nacional por meio de seus Comitês Olímpicos Nacionais (tal como o Brasileiro, o COB).

As regras do jogo não são apenas garantidas com a organização da competição. É sempre possível que atletas ou federações nacionais tentem interpretar as regras no limite, para que possam conquistar títulos. Não raramente, buscam uma vantagem ilícita, de modo que a igualdade esportiva seja violada. É nesse contexto que aparece o doping de atletas. Para combater essa ilicitude, a estrutura desportiva desenvolveu um Código Antidopagem, cuja administração fica por conta da Agência Mundial Antidoping (WADA). Esta possui uma configuração hibrida: Estados e entes privados esportivos possuem representação na política e na regulação antidopagem. Aqui, Estado e entidades privadas se unem em torno de valores jurídicos como garantia da saúde e igualdade desportiva.

Por fim, como centro da ordem jurídica, participa a Corte Arbitral do Esporte (CAS ou TAS), que determina a validade ou invalidade de seu programa normativo, isto é, dos regulamentos das Federações Internacionais e de contratos internacionais entre atletas e clubes, além de determinar se o comportamento do atleta ou entidade esportiva está em consonância com a regulação da $\mathrm{WADA}^{4}$. Como um pressuposto básico para a participação nas Olimpíadas, o COI fez valer as decisões do CAS, exigindo que todos os entes desportivos acatem as decisões e reconheçam, em seus próprios estatutos, essa exigência olímpica (FOSTER. 2019, p. 1).

Se, por um lado, para a vinculação às regras estatais, basta ser cidadão ou estar em território estatal, no caso do esporte, ao contrário, depende-se da autonomia privada de seus participantes, isto é, na aceitação das regras pelos associados (atletas, treinadores, dirigentes etc.) e do

2 Há alguns esportes que não estão incluídos na organização olímpica, tais como esportes sem monopólio da administração esportiva (caratê) ou esportes ditos profissionais (boxe) ou esportes/organizações que não possuem interesse em se vincular às regras e estrutura olímpica (MMA/UFC).

3 Um exemplo é a Confederação Brasileira de Vôlei (CBV), que ainda reconhece as federações locais

4 Em caso recente, o CAS proibiu a participação da Comitê Olímpico da Rússia em participar das Olímpiadas de Inverno por descumprir as regras da WADA (sentença nº 2020/O/6689 WADA v/ RUSADA, disponível em https://www.tascas.org/fileadmin/user_upload/CAS_Media_Release_6689_decision.pdf). 
estabelecimento de hierarquia entre instituições e de monopólio esportivo (VAN KLEEF, 2014) ${ }^{5}$. Isso inclui o aceite do atleta, que se adequa às regras do jogo e ao entorno profissional exigido para que possa participar das competições (ROTHEL, 2007, p. 757). Ainda que exista algum entrelaçamento, a estrutura privada das entidades desportivas tenta se afastar da apreciação jurídica por atores estatais ${ }^{6}$, tendo em vista não somente o princípio da igualdade, mas também a autonomia da ordem desportiva (FOSTER, 2019, p. 2).

O fato é que a lex sportiva é uma ordem jurídica. Em termos da teoria dos sistemas, tal ordem é mediada por um código binário (lícito/ilícito), por programas normativos que geram conteúdo jurídico e estabilizam expectativas normativas. Livros de regras e estatutos foram reescritos no nível nacional ou internacional, reivindicando autonomia e ganhando forma de documento legal (NEGÓCIO, 2014, p. 137). Por esse contexto associativo e dependente das competições desportivas, a lex sportiva se torna uma ordem extremamente eficaz na tomada de decisões. E o termo lex sportiva representa essa aplicabilidade generalizada de normas jurídicas sem a necessidade de uma vinculação local ${ }^{7}$. Por, não raramente, lidar com problemas transconstitucionais, tal ordem também nos permite repensar conceitos de direito público por uma entidade eminentemente privada.

\section{SobERANiA JURÍDICA}

O tratamento de soberania como temática parte, geralmente, de duas vertentes: uma política e outra jurídica. O campo do poder/ não-poder confronta o código do lícito/ilícito no campo da soberania. Um debate tradicional está entre Schmitt e Kelsen. Para Schmitt, soberano é quem decide em um caso limítrofe, isto é, em um Estado de exceção (Schmitt, 2006, p. 7): a ordem jurídica repousa em uma decisão e não em uma norma (Schmitt, 2006, p. 10-11). A decisão nessa situação liberta-se de qualquer vínculo normativo; "torna-se absoluta em sentido real". Para embasar tal ponto, o autor se apoia no Estado de exceção, em que há a suspensão do Direito em prol da autoconservação (Schmitt, 2006, p. 7). Assim, é somente o soberano que decide, definitivamente, sobre se tal situação "normal é realmente dominante", tendo, portanto, o monopólio da última decisão (Schmitt, 2006, p. 13-14). O "monopólio decisório" definiria a soberania jurídicoestatal (Schmitt, 2006, p. 14). Consagra, portanto, que a vinculação do poder supremo fático e jurídico é o "problema principal da soberania" (Schmitt, 2006, p. 18). Assim, "a realidade jurídica depende de quem decide, mas surge do aspecto juridicamente concreto" (Schmitt, 2006, p. 32).

Kelsen, em contraponto a Schmitt, pensa que o Estado só pode ser considerado soberano, porque há uma ordem jurídica como ponto de partida (2000, p. 544). Para o autor "apenas uma ordem normativa pode ser 'soberana', ou seja, uma autoridade suprema, o fundamento último de validade das normas que um indivíduo está autorizado a emitir como 'comandos' e que os outros são obrigados a obedecer" (KELSEN, 2000, p. 545). O poder factual se submete ao dever-ser: o Estado enquanto conceito jurídico está separado do Estado como conceito sociológico (KOSKENNIEMI, 2005, pp. 226-27). A validade (objeto do dever-ser) só pode ser derivada de uma

5 É a regra, mas há Federações Internacionais que não possuem controle sobre certas instituições desportivas, muito embora possam ter atletas que participam das competições internacionais. É o que ocorre com a Federação Internacional de Basquete (FIBA) e a National Basketball Association (NBA).

6 Isso não exclui que não seja possível ocorrer, dado que, ainda que as instituições sejam transnacionais, elas se submetem a alguma ordem jurídica nacional e/ou supranacional.

7 Isso não exclui alguma interferência estatal ou supranacional na organização do direito desportivo, mas o que fica claro é que, apesar de uma organização se estabelecer em um país, pode ela se mudar para algum outro país menos intervencionista. 
norma acima, até a norma hipotética fundamental, sendo o Estado dependente disto. Nesta ótica, "soberania" é apenas uma forma de dizer que a ordem legal é válida (KOSKENNIEMI, 2005, pp. 226-27).

Koskenniemi entende utópica a visão de Schmitt quando expressa a rejeição total à ênfase realística, falhando em dar proteção aos Estados que assumiram liberdade e independência inicial; ao mesmo tempo que soa apologista o argumento de Kelsen quando falha em distinguir entre a decisão real e a decisão legítima, além de não conseguir proteger a igualdade de outros Estados e de não explicar a restrição externa ao poder do Estado (2005, pp. 228). Parece, porém, que o debate pode ganhar nova forma e ir além desse espaço territorialmente definido. Para tanto, o conceito de soberania tende a ser "reduzido à dimensão normativo-jurídica, enquanto nãosubordinação da ordem ou instituição jurídica" (NEVES, 2008, p. 157).

Aqui, a noção de soberania está conectada ao que se construiu como Estado Democrático de Direito, isto é, sob a ótica dos sistemas político e jurídico. Por um lado, a soberania será compreendida como "autonomia funcional condicionada e territorialmente determinada do sistema político" como forma de proteção a outras interferências sociais (NEVES, 2008, p. 159). Por outro lado, a soberania significará "a autonomia operacional do sistema jurídico" (NEVES, 2008, p. 160). A Constituição poderá ser definida como "mecanismo da soberania do Estado enquanto organização central ou centro de observação de dois sistemas estruturalmente acoplados, a política e o direito" (NEVES, 2008, p. 161). Assim, a Constituição funciona como mecanismo que retira o paradoxo da relação poder e licitude, de modo que entrelaça hierarquias na relação do poder positivado pelo direito, assim como a licitude fica condicionada à alteração permanente da vinculação política (NEVES, 2008, p. 161).

Entendo que o sistema jurídico comporta outras ordens sociais não-estatais (TEUBNER, 2004, p. 999), a soberania jurídica não sentirá necessidade de território para se validar ou fazer uso "de monopólio da força". Isso também ajuda a explicar a eficácia das decisões de ordens transnacionais, em especial, da lex sportiva. O pluralismo legal global, assim, nem sempre vai seguir "fórmulas de unidade legal, nem de ideal teórico de uma norma hierárquica" (TEUBNER, 2004, p. 1003). A soberania jurídica será global, fragmentada e, por vezes, autônoma ao Estado. Uma análise pertinente está na sentença n $\mathrm{n}^{\circ}$ 2008/A/1572;/1632;/1659. - 13 de novembro de 2009. - Gusmão c/ Federação Internacional de Natação (FINA) ${ }^{8}$. Ela apresenta o exemplo de banimento de uma atleta por toda a vida nas competições internacionais esportivas. Esta sentença vai mostrar uma percepção diferente sobre o mesmo problema quando existem duas ordens jurídicas soberanas interessadas: a lex sportiva e a ordem jurídica brasileira.

A brasileira Rebecca Braga Gusmão era nadadora de alta performance e de nível internacional. Por isso, era afiliada à Confederação Brasileira de Desportos Aquáticos (CBDA). A atleta recorreu de três decisões da Turma de análise dos casos de Doping da FINA (DP), que determinou violação das regras antidoping. Duas delas se referem à presença de uma substância proibida encontrada na amostra coletada da atleta nos testes antidoping conduzidos em 25 e 26 de maio de 2006 (TAS/A/1632) e em 13 de julho de 2007 (TAS/A/1572), respectivamente. A terceira violação de regra alegada refere-se à adulteração do controle conduzido em 12 de julho de 2007 e outro conduzido em 18 de julho de 2007 (TAS/A/1659).

Durante o campeonato de natação em 2006, a atleta foi submetida a um teste feito pela CBDA em 25 e 26 de maio de 2006. As amostras foram enviadas para um laboratório credenciado pela WADA em Montreal, Canadá. A amostra do dia 26 de maio apresentou testosterona de origem exógena. A FINA recomendou que a CBDA continuasse a ouvir o caso mesmo depois

8 Disponível em http://jurisprudence.tas-cas.org/Shared\%20Documents/1572,\%201632,\%201659.pdf\#search= 2008\%2FA\%2F1572. 
que o diretor médico tenha sugerido que não havia base para a punição da atleta na primeira amostra. Em audiência realizada pela CBDA em maio de 2007, a atleta confirmou que todas as amostras foram coletadas corretamente e não se opôs ao procedimento. Considerando as diferenças entre CBDA e FINA na interpretação dos resultados laboratoriais, a Turma julgadora da CBDA decidiu não suspender a atleta. A FINA solicitou ao laboratório a análise da amostra B (controle), que confirmou resultados consistentes para testosterona exógena. De acordo com os resultados, a FINA solicitou à CBDA que organizasse uma audiência imediatamente para considerar os resultados desfavoráveis e para emitir uma decisão final o mais rápido possível. Mesmo após a amostra B, a CBDA ainda mantém sua posição, pois não pode garantir a presença de doping e, portanto, não pode punir o atleta. A FINA recorreu ao TAS, que se recusou em julgar, pois as próprias esferas da FINA não foram exauridas.

A FINA promoveu audiência por meio de sua Turma recursal antidoping. A atleta nomeou o Dr. de Castro como perito. A Equipe Antidopagem da FINA decidiu em sua decisão que os atletas violaram os regulamentos na forma de substâncias proibidas. De acordo com o curso, foi comprovada de forma convincente a existência de testosterona exógena. A partir de 17 de julho de 2008, a atleta foi condenada, não podendo participar da competição de 2 anos. A atleta recorreu à TAS em 12 de agosto. 2008.

A atleta participou da competição de natação dos Jogos Pan-americanos, realizada no Rio de Janeiro de 13 a 29 de julho. Na ocasião, ela se submeteu a dois testes antidoping de 12 a 18 de julho de 2007, que deram suporte ao recurso TAS/A/1659. As amostras foram enviadas a um laboratório credenciado em Montreal, Canadá, para análise. Em 30 de julho de 2007, o laboratório descobriu que a amostra continha testosterona exógena. Isso levou à notificação da FINA de que a atleta será temporariamente suspensa de 2 de novembro de 2007 até a audiência da Turma antidoping da FINA. Após o anúncio da penalidade, a atleta se apresentou ao público da Equipe Antidoping da FINA e, no dia 12 de março, foi julgado que a atleta havia violado as regras antidoping e foi punido com desclassificação de dois anos. Contudo, com o processo anterior correndo, essa poderia ser a segunda punição, resultando na inelegibilidade para toda a vida, o que fez a Turma esperar o resultado do processo anterior para pronunciar se a pena seria para toda a vida.

Ainda no Pan-Americano, ela foi submetida a um teste, fora da competição, conduzido pelo Comitê Organizador dos Jogos. As amostras enviadas ao laboratório, credenciado pela WADA, atestaram negativos para as amostras coletadas no dia 12 de julho. Todavia, o laboratório informou que havia claras indicações de uma elevada alteração, o que sugeriu que uma avaliação mais profunda na amostra (reforçado por um observador internacional da Agência, que requereu ao laboratório o perfil das amostras coletadas nos dias 12 e 18 de julho de 2007, revelando ser de diferentes pessoas). No dia 27 de outubro de 2007, o laboratório SONDA, credenciado pela Justiça brasileira para examinar análises de DNA para a Polícia Federal, relatou à comissão médica da organização dos Jogos que as amostras eram de diferentes doadores. Uma audiência foi realizada em 27 de julho de 2008. No dia 3 de setembro de 2008, a Turma decidiu que ela era inelegível por toda a vida em razão da segunda ofensa às regras antidoping.

A atleta alegou que, devido à extrema diluição e degradação bacteriana das amostras, não seria confiável estabelecer a presença de testosterona exógena. Além disso, a condição patológica da atleta explicaria a alteração. Por fim, a atleta alegou desvios procedimentais. Analisando os méritos, a Turma do TAS concluiu que a análise era confiável e de origem exógena da testosterona. Além de não constatar nenhum problema procedimental, a Turma acatou a tese de que ela cometeu uma violação a uma regra antidoping (inclusa a acusação de adulteração do controle antidoping cometido pela atleta). 
O TAS afirmou, ainda, que as investigações da polícia brasileira não tinham nenhum efeito vinculante ou prejudicial. De acordo com o artigo R58 do código do TAS a Turma tem de aplicar as regras da FINA, incluindo as regras e padrões de prova que a Turma aplica em sua decisão. A Justiça brasileira, em carta enviada à Turma, afirmou que não existia evidência suficiente para convicção para prosseguir com a acusação contra a atleta. A Turma, em função de seu próprio programa normativo, não podia aceitar a decisão da Justiça brasileira. Portanto, a conclusão da Justiça não afetou a decisão, dado que a corte brasileira, sob o direito penal brasileiro, aplicou diferentes regras para se chegar àquela decisão.

$\mathrm{Na}$ soma de todas as sanções, a Turma decidiu a atleta deveria ser banida por toda a vida do esporte. A sentença apresentou a coexistência de duas soberanias jurídicas em torno do mesmo problema. Ainda que houvesse uma decisão penal que inocentasse a atleta, o TAS fez uso de sua soberania jurídica: não se vinculou ao que foi decidido pela Justiça brasileira, ainda que não excluísse a pertinência do que decidira a Justiça brasileira. Ele dividiu os planos da matéria a serem decididas, ou seja, a Justiça brasileira até poderia condenar a atleta sob os argumentos penais, mas não esportivos. Mesmo entendendo existir pertinência na decisão brasileira, o que reforça a soberania jurídica da lex sportiva é a possibilidade de aplicar uma pena de caráter perpétuo à atleta, muito embora a Constituição brasileira, em seu art. 5, XLVII, "b”, a proíba. Ou seja, em razão de sua soberania jurídica, é fundamental aplicar a legislação transnacional, ainda que exista previsão constitucional contrária. Conclui-se que, antes de se buscar uma horizontalidade entre Estados, é fundamental encontrar uma relação horizontal entre ordens jurídicas, dadas suas respectivas soberanias, que, de fato, não podem ser ignoradas na eficácia de suas decisões.

\section{Cidadania e o ACESSo aOS PROCEDimentos CONSTITUCiOnAis}

A cidadania possui uma conceituação ambígua. Por isso, a leitura que lhe será dada é a de "inclusão de toda a população na "prestação dos sistemas sociais"” (NEVES, 1994, p. 259). A cidadania está vinculada "à auto-referência dos sistemas político e jurídico" (NEVES, 1994, p. 259), sendo ela "incompatível com ingerências bloqueantes e destrutivas de particularismos políticos e econômicos na reprodução do Direito" (NEVES, 1994, p. 259).

O núcleo básico é o princípio da igualdade enquanto "mecanismo jurídico-político de inclusão social", apresentando-se "em uma pluralidade de direitos reciprocamente partilhados e exercitáveis contra o Estado" (NEVES, 2008, p. 175). A crescente constitucionalização de exigências integrativas dos sistemas políticos e jurídicos na sociedade (NEVES, 2008, p. 179) é fruto de três fases: o surgimento da semântica de direitos humanos, orientado na construção e na ampliação generalizada dos direitos de cidadania; o reconhecimento e incorporação estatal da semântica dos direitos humanos em sua Constituição como direito fundamental; por fim, "a concretização das normas constitucionais referentes aos direitos fundamentais" (NEVES, 2008, p. 182).

O fundamental à cidadania é o "acesso generalizado aos procedimentos constitucionalmente estabelecidos e aos benefícios sistêmicos deles decorrentes nos diversos setores da sociedade" (NEVES, 2008, p. 183). A cidadania deriva da esfera pública para os sistemas jurídico e político, e retorna destes para aquela. Portanto, é possível afirmar:

[...] de um lado, a pluralidade de direitos que constitui a cidadania relaciona-se com a diferenciação sistêmico-funcional da sociedade; de outro, com a heterogeneidade de expectativas, valores e interesses que circulam por diversas formas discursivas na esfera pública e exigem tratamento equânime nos procedimentos constitucionais (NEVES, 2008, p. 183). 
Uma das características da cidadania, especialmente no Brasil, é o acesso ao Judiciário. Diante da ordem transnacional desportiva, ele não será mitigado, senão deslocado a um tribunal desvinculado de qualquer Estado. Não somente sob esta óptica, a sentença no 2007/A/1370 e 2007/A/1376, de 11 de setembro de 2008 - FIFA \& WADA c/ Superior Tribunal de Justiça \& Confederação Brasileira de Futebol \& Mr. Ricardo Lucas Dodô, também contribuirá na compreensão da organização e funcionamento da ordem jurídico-desportiva brasileira.

No dia 14 junho de 2007, o atleta Dodô foi selecionado para exame antidoping no Campeonato Brasileiro de Futebol após a partida entre Botafogo e Vasco da Gama. O teste revelou a presença de substância proibida (Fenproporex), sendo um forte estimulante e precursor da anfetamina. Apesar de trazer provas de um laboratório da USP de que foi contaminado por uma capsula de café produzida em farmácia de manipulação, a Comissão Disciplinar lhe impôs uma suspensão de 120 dias. Entendeu que a explicação do jogador era implausível, especialmente a luz dos fatos de que nenhum outro jogador do Botafogo foi testado positivo em qualquer outro jogo. Todavia, ao julgar recurso do atleta, o Superior Tribunal de Justiça Desportiva (STJD), no dia 2 de agosto de 2007, decidiu, por maioria, que o argumento do jogador era válido, sendo ele vítima de contaminação, retirando dele a alegação de que teria sido negligente. Dessa forma, a decisão da Comissão de suspensão do atleta foi reformada.

Não conformadas com a decisão, a CBF, a FIFA e a WADA recorreram da decisão do STJD junto ao TAS, requerendo a suspensão imediata do atleta. Preliminarmente o TAS decidiu que tinha jurisdição para regrar sobre o caso (algo contestado pelo atleta), como também não acatou o pedido de suspensão provisória do atleta. Ainda antes da audiência, manifestando-se por carta, o STJD confirmou sua posição e afirmou que o TAS não tinha jurisdição rationae personae sobre o tribunal nacional, embora aceitando que tinha jurisdição rationae materiae sobre o caso.

Já na audiência, mesmo reconhecendo a independência do STJD, a FIFA e a Agência Mundial Antidoping reforçaram que o TAS tem jurisdição para julgar o caso, dado que o artigo 61 de seu estatuto mais atualizado prevê essa possibilidade. Nesse caso, seus membros são obrigados a incorporar em suas regulações as provisões de administração do doping e que, em caso de exame positivo para a substância proibida, a primeira ofensa exige o cumprimento da pena de 2 anos de suspensão. De acordo com o Código Mundial Antidoping, o jogador não podia meramente alegar, sem provas, que houve contaminação para se eximir da pena. Além de não conhecer os padrões aplicados pela farmácia de manipulação, a Agência Mundial Antidoping também nega que tenha sido contaminado o produto. Entendendo que o jogador foi negligente, que a substância melhora a performance e que não foi mencionado o uso de qualquer suplemento ou medicamento no exame antidoping, pediram para que o atleta fosse suspenso por dois anos do futebol.

O atleta Dodô negou que o TAS tivesse jurisdição sobre seu caso. Afirmou que o Código Brasileiro de Justiça Desportiva não menciona o TAS como um órgão recursal, mas estabelece que as decisões do STJD são finais, vinculantes e não sujeitas a recurso. O jogador ressaltou a independência do STJD, que não tem nenhuma conexão legal com a CBF, conforme previsto no artigo 217 da Constituição Brasileira, que garante o STJD como um tribunal de esporte autônomo e independente, e na Lei Pelé. Alegou que não há previsão recursal no estatuto da CBF e do STJD para a competência do TAS. Além disso, alegou que o artigo 13 do Código Mundial Antidoping, no Brasil, não era efetiva no tempo da alegada ofensa de doping. Expôs que não teve culpa alguma na ingestão das capsulas, eis que ingeriu as capsulas indicadas pelo médico da

9 Disponível em http://jurisprudence.tas-cas.org/Shared\%20Documents/1370,\%201376-O.pdf\#search= 2007\%2FA\%2F1370. 
equipe; ele não questionou a origem das capsulas, pois havia utilizado os serviços da companhia durante dois anos. O atleta afirmou que a pena de dois anos é desproporcional sob as circunstâncias dele, pois não houve culpa. Mesmo no caso de pouca significância de culpa, em um pior cenário, a sanção máxima seria de 360 dias, possivelmente reduzida pela metade para o caso de preferência do Código Disciplinar da FIFA.

Para decidir definitivamente sua competência sobre todos os atores envolvidos, o TAS afirmou que a CBF adere aos regulamentos da FIFA, conforme seu próprio estatuto. O Estatuto da FIFA prevê que, quando exauridos todos os recursos internos, a FIFA e a WADA são competentes para recorrer ao TAS contra decisões envolvendo o doping adotados pelos membros da FIFA. Isso torna a CBF legalmente ligada a uma decisão do TAS. Contudo, tendo em vista o Direito brasileiro e as regras esportivas brasileiras, a Turma arbitral opina que o STJD é um órgão de justiça que, embora independente em sua atividade de julgar, deve ser considerado parte da estrutura organizacional da CBF.

Ao verificar o direito brasileiro, observou-se que o artigo $217, \S \S 1^{\circ}$ e $2^{\circ}$, da CF menciona que a Justiça comum só tem competência quando se tenham exaurido todos os procedimentos. O art. 217 da CF não especifica como os órgãos da justiça desportiva devem ser estruturados nem se eles são independentes ou como é montada interna ou externamente a estrutura organizacional das federações esportivas. $\mathrm{O}$ art. 217 deixa a regulação ordinária para tais detalhes ao direito ordinário. Citando o art. 69-71 do estatuto da CBF e art. 23, I, da Lei Pelé, ("Os estatutos das entidades de administração do desporto, elaborados de conformidade com esta Lei obrigatoriamente regulamentar, no mínimo: I- instituição do Tribunal de Justiça Desportiva, nos termos desta Lei"), o TAS entendeu que o STJD é um órgão de Justiça independente e autônomo. Nem por isso o STJD não está obrigado a cumprir as regulações da FIFA de aplicação universal.

Embora admirado com a separação de funções na $\mathrm{CBF}$, que respeitava os julgados do STJD, isso não alterava o fato de que este é instituído pelo Estatuto e dependente de financiamento administrativo da Confederação Brasileira de Futebol. O TAS, ao contrário, não depende da existência, por exemplo, do COI para existir: não depende financeiramente, nem esportivamente, podendo existir somente com a presença de outras Federações Internacionais. Dessa forma, o TAS concluiu que qualquer decisão do STJD deve ser considerada como decisão da CBF, o que a torna responsável em face da FIFA, mesmo pelas decisões de seu Tribunal. Consequentemente, a Turma tem jurisdição rationae materiae sobre a decisão recorrida, mas não tem jurisdição rationae personae contra o STJD.

Merece consideração a seguinte reflexão: na Justiça desportiva brasileira atualmente, não há um só órgão responsável pelo julgamento de todos os esportes nacionais, mas sim, de forma fragmentada, pelo esporte representado. A única coisa que dá algum parâmetro procedimental, de âmbito nacional, a todos esses tribunais é o Código Brasileiro de Justiça Desportiva - Resolução n 29 do Conselho Nacional do Esporte; a Lei Pelé - Lei 9.615/98; e a Constituição Federal. Isso implica que as mais diversas legislações transnacionais dos diferentes esportes terão outros tipos de regras recursais que nem sempre seguirão os parâmetros nacionais. Assim, o Código Brasileiro da Justiça Desportiva, conforme o próprio TAS, só é relevante em nível nacional. Mesmo não sendo importante para a fundamentação de sua competência, acrescenta o Tribunal Arbitral do Esporte que a Lei Pelé, em seu artigo $1^{\circ}, \S 1^{\circ}$, expressa que a prática desportiva é objeto das regulações nacionais e internacionais. É também por isso que o TAS se afirmou competente a julgar o atleta, dado que ele é registrado pela CBF e, ao assinar seu contrato, sabe explicitamente que se obriga a cumprir suas obrigações constantes no contrato de trabalho registrado na CBF e seus aditamentos, bem como respeitar o regulamento dessa entidade. 
Aplicando primariamente as regras esportivas internacionais (ou, mais precisamente, transnacionais) e, subsidiariamente, as regras nacionais, o TAS acatou as razões das entidades transnacionais e acrescentou que o jogador é o responsável pela presença da substância proibida em seu corpo, não sendo necessária a comprovação de culpa ou intenção ou consciência de uso do jogador para estabelecer uma violação antidoping. Como não foi mostrada a ausência de culpa ou culpa insignificante, aplicou-se a pena de dois anos de suspensão ao atleta, não se estendendo aos clubes pelos quais defendeu.

É de se concluir que o acesso generalizado aos procedimentos constitucionais, como característica da cidadania, é deslocado à esfera transnacional, quando referente ao acesso ao Judiciário. Esse deslocamento, uma verdadeira deslocalização, por um lado, limita o conhecimento da Justiça comum de recursos oriundos da Justiça desportiva (art. 217, §1 $1^{\circ}$ ) - reforçada pela proibição das Federações Internacionais - o que também dificulta a aplicação de preceitos constitucionais aos casos nacionais; por outro lado, a deslocalização permite a garantia constitucional, em âmbito global, da concretização multilocalizada do princípio da igualdade, tendo em vista que os casos, principalmente disciplinares, terão considerações iguais. Se não há uma transnacionalização da cidadania por completo ${ }^{10}$, seu caráter de acesso aos preceitos constitucionais parece cada vez mais ganhar a qualidade de "espessuras insuspeitas", ou, mais especificamente, de materialidade não prevista em estudos tradicionais.

\section{NACIONALIDADE E UM TERCEIRO CRITÉRIO}

Em artigo publicado no jornal Frankfurter Allgemeine Zeitung em 1990, Luhmann afirmou que no mundo, apesar de não viver mais fortemente a dualidade capitalismo/socialismo, havia um receio com o "nacionalismo tribal, sem possibilidades econômicas e muitas vezes carregado de combustível religioso" (LUHMANN, 1990). A ideia de nação, todavia, perdia significado na sua força integradora e na sua soberania externa. Esse sentido é reforçado pela fugacidade e velocidade de temas como moda, mercado financeiro e esfriamento/aquecimento de relações políticas, sendo todos mediados por meios de comunicação em massa (e por meios digitais). Para toda onda, porém, existe um refluxo: o sentimento de pertencimento e enraizamento a um local parecem se deslocar a uma esfera legítima do esporte (no caso, o futebol), cujo sistema é sem propósito. Nele se carrega a leveza (e velocidade), que aparece na lógica do jogo e nos componentes de mercado do esporte, ao mesmo tempo em que carrega, também, o peso da estabilidade e identificação com que os torcedores podem se comprometer a sentimentos nacionais. Embora se identifiquem recorrentes discursos nacionalistas, no momento atual, o esporte ainda parece ser o local de legitimidade simbólica do nacionalismo.

A nacionalidade, portanto, não se restringe a considerações das ordens jurídicas nacionais e da ordem internacional (principalmente em temas que tocam na condição do refugiado). Nas ordens nacionais, a nacionalidade vai se diferenciar da cidadania, posto que esta absorverá, em grande medida, o direito de participação política, enquanto aquela se restringirá à ligação jurídica que a pessoa possui com o Estado, não necessariamente incluindo a participação política.

A determinação da nacionalidade válida para a participação de eventos esportivos de grande porte tem sido um dos grandes desafios a serem enfrentados pela lex sportiva. Nos últimos anos, foi possível presenciar uma crescente naturalização de atletas que apenas visavam a participação em competições internacionais. Da mesma forma, havia interesse dos Estados em naturalizar atletas com o intuito de angariar melhores resultados nas competições. Com tantas

\footnotetext{
${ }^{10}$ Mostrando uma tendência desse fenômeno (apesar de possuir uma visão diferente de cidadania), BOSNIAK, 2000.
} 
regras diferentes sobre o tema, era necessário ir além das regras nacionais e internacionais para delimitar o espaço esportivo.

Na sentença da Turma ad hoc (J.O. Sydney) no 00/001, de 13 de Setembro de 2000, United States Olympic Committee (USOC) and USA Canoe/Kayak c/ International Olympic Committee $(\mathrm{COI})^{11}$, o atleta Angel Perez, que nascera em Havana e competiu por Cuba em 1992 nos Jogos Olímpicos de Barcelona, não retornou ao seu país após uma competição no México em 1993. Ao fugir para os Estados Unidos, pediu asilo sob o direito norte-americano e nunca retornou a Cuba desde então. Em 1994, casou-se com uma cidadã norte-americana, com quem teve um filho em 1995. No mesmo ano, ganhou o status de "Estrangeiro residente" nos EUA.

Respeitando as regras da FI de Canoagem, competiu pelos EUA no mundial de 1997, 1998 e 1999. Neste ano de 1999, o atleta obteve a cidadania norte-americana. Em agosto de 2000, Comitê Olímpico dos EUA requereu que o COI garantisse o direito de participação do atleta nos Jogos Olímpicos de Sydney. O COI negou sob os seguintes argumentos: o atleta já representou Cuba; foram menos de três anos desde que o atleta se tornou um nacional dos EUA; e o CON de Cuba não concorda em reduzir o período de três anos referidos na legislação da Carta Olímpica.

Os requerentes alegaram que a qualidade de "nacional" e "cidadão" poderiam ser igualados como demonstrado pelo direito de imigração dos EUA, que definia um nacional como um cidadão dos EUA, ou uma pessoa que, embora não fosse um cidadão dos EUA, devia permanente fidelidade ao país. Os demandantes arguiram que desde que o atleta abandonou seu país, seus direitos como um nacional cubano se tornaram nulos.

O TAS em suas considerações, afirmou que o demandante não provou que conseguiu o status de nacional por um período de três anos: a condição de "estrangeiro residente" não é suficiente para tal caracterização, pois ele somente obteve a condição de nacional após a obtenção da cidadania em 1999. Afirmou que, em casos assim, o TAS deve olhar para além dos dois direitos nacionais e decidir qual é a nacionalidade predominante. Embora perceba que a distinção entre nacionalidade e cidadania é correta, o Tribunal declarou que apenas ocorreu o estabelecimento de fato da nacionalidade, mas não jurídica. Trazendo para o contexto transnacional, os demandantes não conseguiram provar que seus fundamentos foram definidos pela Carta Olímpica, ou sob o direito internacional, ou sob a ordem norte-americana. A Turma não quis produzir uma regra nova, tendo em vista a existência de uma regra clara. Acrescentou, por fim, que não existem argumentos de "justiça", para ser derivado da Carta Olímpica, como o reconhecimento que a prática do esporte é um direito humano fundamental, que deveria, sob tais circunstâncias, ser criado um limite de tempo exterior de inelegibilidade olímpica. Para o TAS, esse tipo de caso não merece uma readequação da regra a partir de "valores" estabelecidos em Carta Olímpica.

Wollmann entende que, nos últimos anos, a maioria dos esportes não mudou substancialmente suas exigências de elegibilidade, se mantendo normativo quanto às mudanças externas (leia-se: do direito internacional) relativas à nacionalidade e o aumento do fluxo migratório. Isso porque, além de, por critérios desportivos (no caso, inflar o resultado no quadro de medalhas), os Jogos Olímpicos buscaram criar outras alternativas para os refugiados, tal como disputar medalhas sob a bandeira da Equipe Olímpica de Refugiados (2018). A crescente mobilidade não denuncia apenas uma ausência de exclusividade no que tange à nacionalidade, mas também o crescimento de uma "nacionalidade Olímpica” (KOSTAKOPOULOU; SCHRAUWEN, 2014).

\footnotetext{
11 Disponível em http://jurisprudence.tas-cas.org/Shared\%20Documents/OG\%2000-001.pdf\#search= n\%C2\%BA\%2000\%2F001\%20Canoe\%2FKayak.
} 
Embora o tema não seja necessariamente constitucional em todas as nações, ele se comporta sob o domínio da soberania jurídica. Esta permite a promoção de uma terceira via desnacionalizada e deslocalizada no que se refere à determinação da nacionalidade. $\mathrm{O}$ intuito disso não é negar os critérios das ordens estatais, mas permitir que um preceito fundamental das ordens desportivas seja possível: a sinceridade das competições desportivas. A ideia, portanto, é evitar que a competição esportiva seja um mero instrumento de promoção de Estados "vencedores", que, por vezes, compram a nacionalidade do atleta visando seu alto padrão de performance esportiva. A deslocalização desses critérios não visa a medalha como fruto do país que compra a nacionalidade de um atleta, senão como fruto do atleta, representando regularmente o seu país.

\section{CONCLUSÃo}

A percepção sobre soberania enquanto estudo constitucional merece uma divisão de sua observação, isto é, uma separação entre soberania política e jurídica. Dessa forma, verificou-se que entender a soberania jurídica, como autonomia operacional do sistema jurídico, permite dar um lugar coerente às ordens jurídicas transnacionais na sociedade mundial. Isso, igualmente, autoriza novos olhares a respeito de temas dependentes, como o acesso ao Judiciário, a característica cidadã do acesso aos procedimentos constitucionais e o critério de determinação da nacionalidade. Todos esses temas partem de uma premissa localizada, para chegar a uma conclusão deslocalizada. Portanto, reforça-se a necessidade de como um terceiro critério - no caso, privado - pode ser relevante para a determinação de temas originariamente estatais. A conceituação clássica desses temas não permite a inserção de atores transnacionais. Ao compreender que os atores transnacionais estão inseridos na solução desses problemas, os conceitos clássicos tendem a uma readequação.

\section{REFERÊNCIAS}

BOSNIAK, L. “Citizenship Denationalized”. In: Indiana Journal of Global Legal Studies. Vol. 7, Issue 2 (Spring 2000), pp. 447-510.

BOTZEM, S.; QUACK, S. Contested rules and shifting boundaries: International standard setting in accounting, WZB Discussion Paper, No. SP III 2005-20.1, 2005.

DI FABIO, U. Das Recht offener Staaten. Tübingen: Mohr Siebeck, 1998.

FICHER-LESCANO, A.; TEUBNER, G. "Regime-Collisions: The Vain Search for Legal Unity in the Fragmentation of Global Law", in: Michigan Journal of Internacional Law, Vol.25, n. 4, 2004, pp. 999-1046.

FISCHER-LESCANO, A; TEUBNER, G. Regime-Kollisionen. Zur Fragmentierung des globalen Rechts. Frankfurt am Main: Suhrkamp, 2006.

FOSTER, K. Global Sports Law Revisited. Entertainment and Sports Law Journal, 17: 4, 114. 2019.

KELSEN, H. Teoria geral do direito e do Estado. São Paulo: Martins Fontes, 2000.

KOKOTT, J. Die Staatsrechtslehre und die Veränderung ihres Gegenstandes: Konsequenzen von Europäisierung und Internationalisierung, in: 63 Tagung der VDStRL, Berlin: Walter de Gruyter, 2003. 
KOSKENNIEMI, M. From Apology to Utopia. The Structure of International Legal Argument. Reissue with a New Epilogue. Cambridge: Cambridge University Press, 2005.

KOSTAKOPOULOU, D.; SCHRAUWEN, A. Olympic citizenship and the (un)specialness of the national vest: Rethinking the links between sport and citizenship law. International Journal of Law in Context, 10(2), 143-162,(2014).

LEYENS, P. C. Selbstbindungen an untergesetzliche Verhaltensregeln Gesetz, Vertrag, Verband, Publizität und Aufsichtsrecht. In: Archiv fuer die civilistische Praxis 215(5), 2015, 611-654

LUHMANN, N. Die Politik der Gesellschaft. Suhrkamp: Frankfurt am Main, 2000.

LUHMANN, N.. Der Fußball. Frankfurter Allgemeine Zeitung, (4.7.1990). Texto em espanhol disponível no site https://sistemassociales.com/el-futbol-por-niklas-luhmann/.

MAYER, F. C. Der Wandel von Staatlichkeit im Prozess der Internationalisierung, In: Vol. 28, No. 2, April 2005.

NEGÓCIO, Ramon. Lex Sportiva: Da eficácia jurídica aos problemas transconstitucionais. Direito. UnB, Brasília v.1, n.2, jul./dez 2014, p. 133-159.

NEVES, M. Entre subintegração e sobreintegração: a cidadania inexistente. Dados - Revista de Ciências Sociais, Rio de Janeiro, v. 37, n. 2, p. 253-275, 1994.

NEVES, M. Entre Têmis e Leviatã: uma relação difícil: o Estado Democrático de Direito a partir e além de Luhmann e Habermas. [tradução do autor]. $2^{a}$ ed. São Paulo: Martins Fontes, 2008.

ROTHEL, A. H. Lex mercatoria, lex sportiva, lex technica - Private Rechtsetzung jenseits des Nationalstaates? In: JuristenZeitung, 10. August 2007, 62. Jahrg., Nr. 15/16, pp. 755-763.

SCHMITT, C. Teologia política. Tradução: Elisete Antoniuk. Belo Horizonte : Del Rey, 2006.

TEUBNER, G. Verfassungsfragmente. Berlin: Suhrkamp, 2012.

VAN KLEEF, R. The legal status of disciplinary regulations in sport. Int Sports Law J 14, 24-45, 2014.

VESTING, T. Die Staatsrechtslehre und die Veränderung ihres Gegenstandes: Konsequenzen von Europäisierung und Internationalisierung, in: 63 Tagung der VDStRL, Berlin: Walter de Gruyter, 2003, S. 41-100. Perritt Jr., Henry H., Towards a Hybrid Regulatory Scheme for the Internet, In: University of Chicago Legal Forum, Volume 2001, Issue 1 Article 8, 216.

VESTING, T. Rechtstheorie: Ein Studienbuch. München: C.H. Beck, 2015.

WOllmanN, A. S.. Recent Trends in Nationality Requirements in Olympic Sports. In: Netherlands International Law Review volume 65, pages359-390 (2018).

Submetido em: 20 dez. 2020.

Aceito em: 25 maio 2021. 